\title{
Cultural Capacity and Development; the case for flexible, interdisciplinary research in remote Aboriginal and Torres Strait Island communities
}

\author{
Sam Osborne \\ University of South Australia \& CRC for Remote Economic Participation \\ samuel.osborne@unisa.edu.au
}

\begin{abstract}
Policies in relation to remote Aboriginal and Torres Strait Islander communities tend to adopt a logic of intervention, where current policy discourse has been narrowed to measures of school attendance, workforce participation and community safety (see Gordon, 2015). In this context, culture is sometimes viewed as unimportant, or even a problem to be overcome within efforts to 'Close the Gap' (Abbott, 2015) between Aboriginal and Torres Strait Islanders and other Australians. This paper draws on the work of Arjun Appadurai, who argues that strengthening cultural capacity, more specifically, the 'capacity to aspire' and 'voice' (Appadurai, 2004, p. 66) generates future-oriented thinking, foundational to notions of development.
\end{abstract}

Two case studies are shared as examples of remote community research methodology in practice and where the logic of strengthening cultural capacity has been applied. In each case, this approach has required flexibility, working across research disciplines, and complex negotiations across points of significant epistemological difference as local voices and aspirations are privileged. Methodological adjustments are required and negotiated for strengthening local voices, language and conceptual development in each case, and the emergence of a language of aspiration and future thinking informs the analysis.

Finally, in arguing for institutional structures that might assist in strengthening cultural capacity in remote communities, the concept of a tristate hub is proposed. Such a model offers potential for 'decolonial knowledge-making' (Nakata et al., 2012) and pursuing research-informed social and economic justice in remote Aboriginal and Torres Strait Islander communities.

\section{Introduction}

Current government priorities work from a logic of intervention and the language of Closing the Gap (Australian Government, 2014) through measuring and comparing 'gaps' between Aboriginal and Torres Strait Islander and other Australians in health, education and life expectancy - among others. This logic and language can position remote Aboriginal and Torres Strait Islanders, their communities and their cultures as being behind, even lesser in the minds of policy makers, and has created a sense of a problem in need of a solution. Appadurai advocates for a strengthening cultural capacity approach to address issues of poverty and social inequity, as opposed to institutional tendencies towards the logic of intervention and philanthropic catch up. Appadurai's (2004) notion of 'cultural capacity' (p.63) is a starting point for pursuing social and economic justice in remote Aboriginal and Torres Strait Islander communities, therefore privileging local voices in remote Indigenous research is vital for generating future-oriented narratives towards social and economic justice. In Pearson's essay, 'A Rightful Place' (2014), he questions whether the institutions of government and those who 
shape Indigenous policies and funding priorities are able to imagine a space between notions of culture and development. He suggests culture tends to be viewed through an anthropological lens as being anchored in the past, whereas notions of development that are firmly entrenched in the neoliberal imagination represent the pathway to improving Indigenous lives.

Two short case studies provide examples of research that demonstrate the importance of local language, culture and cultural capacity as a rich source for generating knowledge and informing notions of the future that can practicably be taken up for 'the re-building of Indigenous lives and communities' (Nakata et al., 2012, p. 124). In the context of the remote research described in the case studies, flexible and interdisciplinary methods and structures are required in adopting a strengthening cultural capacity approach.

The research described in the case studies aligns to the work of the Remote Education Systems (RES) project, which sits within the Cooperative Research Centre for Remote Economic Participation (CRC-REP, see crc-rep.com.au). RES has gathered and analysed data from remote education stakeholders across Australia with a view to identifying ways that outcomes for Aboriginal and Torres Strait Islander students in remote schools can be improved, and what the linkages between those improvements and remote economic participation might be. As part of the CRC-REP, RES research methodologies have been designed to inform policy and government, working from the demands and voices of remote Aboriginal stakeholders. In the tristate region (the region where Western Australia, South Australia and the Northern Territory meet) of remote Australia, this has occurred through surveys, qualitative research methods, collaborative research projects, focus groups and supporting remote Aboriginal educators and stakeholders in public presentations and publications (see Burton \& Osborne, 2014; Minutjukur \& Osborne, 2014; Minutjukur et al., 2014; Osborne et al., 2014; Tjitayi \& Osborne, 2014).

\section{My position}

I am an 'outside' researcher (Foley, 2003; Martin, 2006; Smith, 1999), but with a sense of membership within the remote educational leadership alumni, having worked as a remote school principal, and with an unusual degree of access, particularly in tristate remote communities where familial ties and local language proficiency 'place me' differently within the 'contact zone' (Rigney \& Hemming, 2014). 'Entanglements' (Adams, 2015) of personal and professional relationships and reciprocal obligations need to be recognised as points of potential conflict, but also as providing for alternative modes of engagement through which research has potential to strengthen 'cultural capacity' (Appadurai, 2004, p. 63).

This environment of close relationships and reciprocal obligation ('ngapartji ngapartji', see Tur, Blanch, \& Wilson, 2010) places a double burden of responsibility for ethical engagement in research activity. I need to be careful that the research work I am involved in leaves local community members feeling positive and empowered through the work as these relationships will continue well beyond the life of any research project or activity and much is at stake if research is felt to have been exploitative or misrepresentative in any way. Feminist scholars (Haraway, 2004; Harding, 1992), critical theorists (Delpit, 1993; Ladson-Billings, 1999; Milner, 2008) and Indigenous scholars (Bishop, 2011; Martin, 2006; Moreton-Robinson, 1998; Nakata, 2007f; Smith, 1999) argue the importance of researchers being aware of, and accounting for the implicit cultural, systemic and institutional bonds that inform researcher assumptions, priorities and methodological approaches, particularly when working in 'other' communities (Delpit, 1993; Sarra, 2011; Smith, 1999) where significant points of cultural, epistemological and socioeconomic difference exist. These are fundamentally important ideas when engaging in remote Aboriginal community research as such interactions are largely held 'on location' where remote Aboriginal community members are typically located as subordinate in relation to the various institutions and positions of ordained power. 


\section{Culture and development}

In 'The capacity to aspire', Appadurai (2004) challenges 'deep-seated images of the opposition of culture to economy' (p. 59), where 'culture' can be viewed as an impediment to notions of 'development' (p. 59). Rather, Appadurai argues 'it is in culture that ideas of the future, as much of those about the past, are embedded and nurtured' (p. 59), describing culture as 'a dialogue between aspirations and sedimented traditions' (p. 84). Drawing on Taylor's (1992) concept of the 'politics of recognition... an ethical obligation to extend a sort of moral cognizance to persons who shared worldviews deeply different from our own' (p. 62), Appadurai seeks to 'strengthen the idea of aspiration as a cultural capacity' (p. 62), stating 'the issue is whether cultural recognition can be extended so as to enhance [economic] redistribution (see especially Fraser, 2001; Fraser \& Honneth, 2003)' (p. 63).

Appadurai's theoretical contentions are grounded in practical actions within poor communities in Mumbai, India (see Appadurai, 2004, 2006). Whilst this is far removed from the remote Aboriginal community context that is the focus of this paper, questions of unequal power and society, the impact of neoliberal ideology and the cultural capacity for voice and aspiration as a means for strengthening development offer a useful framework for considering how remote Aboriginal and Torres Strait Islander participation in future-oriented dialogue might address 'some of the most peculiar cruelties of economic exclusion' (p. 82).

Appadurai calls for a 'sea change in the way we look at culture in order to create a more productive relationship between... culture and development' (p. 84). More recently, Aboriginal leader Noel Pearson (2014) called for 'indigenous Australians to become active agents in our own development' (p. 48), stating, 'Our poverty is a development problem that can only be solved by reversing our disenfranchisement' (p. 48). Appadurai's primary concern is addressing poverty and the social structures in India that maintain an unequal society, taking a local community approach to initiating actions that address these concerns. Pearson's arguments also focus around notions of poverty and structured inequality, but the context is vastly different, drawing on historical policies of assimilation, protectionism and annihilation that mark historical interactions with colonialism. Despite differences between Pearson's and Appadurai's descriptions of the conditions of poverty, both contexts are described as conditions of social and economic exclusion and in both cases, the need to challenge the notion of culture and development as binary opposites is argued.

Both Appadurai and Pearson draw on the work of Amartya Sen (Sen, 1984, 1995, 2006) who 'place[s] matters of freedom, dignity and moral well-being at the heart of welfare and its economics' (Appadurai, 2004, p. 63). Pearson (2014) is also drawn to Sen's nuanced approach to the role of identity membership in cultural terms, but also in terms of citizenship and participation in democracy. He argues against 'identity fundamentalism' (p. 32), 'when individuals and groups elevate one level of their identity to the exclusion of all others' (p. 32) complementing Sen's analysis of the 'illusion of singular identity'. Appadurai also draws on Sen's notion of 'cultural capabilities', arguing 'culture is a dialogue between aspiration and sedimented traditions' (Appadurai, 2004, p. 84). These arguments provide fertile ground for exploring the relationship between notions of cultural development and economic participation, and they underpin the collaborative research approach described in the cases below.

Appadurai (2006) explains reflection is required on the very nature of research itself, where ' $[r]$ esearch is so vital to our [institutional] academic common sense that it is not a surprise that there is not a lot of direct reflection on it' (p. 169). In particular,

... what research is, and how research as an idea has evolved in the west, what its meanings are, what people think they are doing when they say they are 'doing 
research' or when they are teaching others to do research. And how do people who are entering the world of research, from outside its western historical home, try to do so? What are the conditions of entry to that world? (p. 169)

Further, Appadurai (2006) argues that globally, '[r]esearch is normally seen as a high-end, technical activity, available by training and class background to specialists in education, the sciences and related professional fields' (p. 167), and that research 'is rarely seen as a capacity with democratic potential, much less as belonging to the family of rights (p. 167). He states:

...the $30 \%$ of the total world population ... who may get past elementary education to the bottom rung of secondary and post-secondary education, ... ought to claim ... the right to research - to gain strategic knowledge - as this is essential to their claims for democratic citizenship. (p. 167)

According to Appadurai's logic, a significant cohort of remote Aboriginal and Torres Strait Islanders are well placed to 'claim...the right to research' in a wider pursuit of a more equal place in Australian society. Indigenous scholars such as Smith (1999), Grande, (2004), Nakata (2007f) and Rigney (1999) have challenged colonialist models and methodologies where unequal power relationships have typified interaction between Indigenous communities and the various institutions. Smith argues that continuing unequal power relationships 'exclude, marginalise and 'Other'... indigenous peoples' (p. 35), where the silencing of Indigenous voices and disregard of Indigenous peoples, histories and knowledges denies 'the power to transform history into justice' (p. 35).

Nakata (2007a) highlights the inadequacy of colonialist, anthropological approaches in generating accounts of Indigenous lives, pointing to the need to acknowledge and account for significant differences between 'Indigenous... and Western knowledge systems' (p. 8), where

[d]ifferences at these levels mean that in the academy it is not possible to bring in Indigenous knowledge and plonk it in the curriculum unproblematically as if it is another data set for Western knowledge to discipline and test. (Nakata, 2007a, p.8)

Aboriginal and Torres Strait Islander experiences of exclusion, subjugation and the devaluing of their cultures explain Indigenous claims for recognition (Fraser, 2009) within the dominant culture context, but Nakata et al. (2012) caution against 'reifying the colonial binaries' (p.127) of Indigenous and Western knowledge systems. Rather, they propose pedagogical tools for critical engagement at the contested and complex 'cultural interface' (Nakata, 2007a). Like Sen, Appadurai and Pearson, Nakata et al. (2012) argue for deeper and more reflective engagement with Indigenous knowledges beyond static, essentialised notions of culture and identity:

For Indigenous students the stakes are high as they seek to honour the intelligence and knowledge of their forbears and transform the possibilities for their families and communities in an everchanging world. They need more than analytical and language tools for simple critique and a decolonising framework that slips them too quickly across the Western-Indigenous binary. (p.136)

It is this space between Indigenous knowledge and Western knowledge, between more traditional understandings of culture and the exploration of continuing worlds of meaning as cultural capacity, that needs further investigation in remote community research, to inform notions of development. 


\section{Methodology}

Indigenous scholars such as Smith (1999), Rigney (1999), Nakata (2007f) and Bishop (2011) point to historical and continuing concerns where colonial approaches to Indigenous research have generated a body of scientific knowledge about Indigenous peoples, their lives and aspirations, but largely exclude Indigenous voices, epistemologies and values in the research process. They call for decolonial research methodologies, including: Indigenist research, where Indigenous researchers undertake Indigenous research (Rigney, 1999), privileging Indigenous peoples, narratives and epistemologies in research (Bishop, 2011; Smith, 1999), and pedagogical tools for more nuanced and contextually responsive engagement at the 'cultural interface' (Nakata, 2007a) between Western (scientific) and Indigenous knowledges (Nakata et al., 2012). These arguments highlight the need for 'outside' researchers (Foley, 2003 , p. 46) to be aware of the institutional assumptions and representations they bring to the Indigenous research context as a beginning point for comprehending and responding to issues of unequal power raised by Indigenous scholars.

A 'power-sensitive' (Haraway, 2004) methodological approach requires time and space not merely to include Indigenous voices in Indigenous research, but to work from Indigenous voices, epistemology and experiences to address continuing unequal, colonial approaches to research. The two case studies that follow describe different methodological approaches developed by researchers in the tristate region. A Participatory Action Research (PAR, see Wadsworth, 1998) methodology was adopted with teams of Aboriginal Community Researchers (ACRs) employed and trained to develop local approaches to commercial research tasks (see Abbott \& Cairney, 2014; Ninti One Ltd, 2014). In the case studies, PAR included translating and re-contextualising mainstream surveys, developing appropriate methodologies, language and concepts to engage community members in research, working across points of significant epistemic difference (see for example, case study two where language and concepts relating to 'mental health' need careful negotiation).

\section{Case Studies}

One of the arguments used in favour of universal, large scale interventions is remote communities are too small, diverse and disparate (see Stafford-Smith \& Huigen, 2009) to generate significant economic opportunities and adequately provide services. This argument encourages remote community members to seek opportunities for economic participation located within large-scale economies such as mining and tourism and in larger townships. Guenther and McRae-Williams (2014) draw on 2011 census data, showing that large scale, externally located employment opportunities are not being taken up by remote Aboriginal and Torres Strait Islanders to any significant degree. They also argue there are plenty of 'real' jobs in remote communities that are frequently filled by non-locals who frequently hold minimal qualifications. With large-scale projects such as mining currently in decline, there is a need for a strengthening cultural capacity approach in remote communities where existing local opportunities can be re-invigorated and new possibilities explored.

As well as describing the research undertaken, these case studies are evidence of the development of local community research as an economic and participatory activity in a region where research is generally undertaken by externally located experts who travel to remote communities, and engage local 'informants' to provide them with information. Ninti One (see nintione.com.au) manages the CRC-REP and provides a structure where research and research-generated action can occur across borders, and between government and non-government entities, bringing remote communities and academic, government, philanthropic and community organisations together. This structure has enabled a strengthening cultural capacity approach, where the cultural capacities of aspiration and voice are critical components of the research that informs local action. 


\section{Demographic context of case studies}

The tristate area is geographically large, covering around $500000 \mathrm{~km}^{2}$ equating to around $6 \%$ of Australia's land mass, with a population of around 5, 500 people (see ABS, 2012; Osborne, forthcoming). The region features strong cross-border family connections and diverse, yet connected languages where desert survival informs a distinct and unique (Strehlow, 1965; Sutton, 2010; Tindale, 1937) social and pedagogical model for interaction across vast tracts of desert country. Anangu are easily able to work within this social frame, but the various state and territory jurisdictions are not so well-equipped to accommodate seamless collaboration. In the case of law and order, it was deemed necessary to be able to work across borders and the Cross-border Justice Act was legislated in 2008 to make this possible (WA Attorney General, 2008). The Ngaanyatjarra Pitjantjatjara Yankunytjatjara Women's Council (NPYWC) operates in a cross-border environment, but health, education, employers and service providers, for example, seem unable or unwilling to find practical and structural avenues for regional collaboration.

\section{Case Study 1}

Between 2010 and 2013, Ninti One undertook a project for Strengthening Community Research in Remote Service Delivery for the then Australian Government Department of Families, Housing, Community Services and Indigenous Affairs, and through this mechanism reviewed aspects of the Local Implementation Plans under the Remote Service Delivery policy in several communities in Northern Territory and South Australia. Through the project, Aboriginal Community Researchers were employed to explore questions of interest to the community within seven interrelated 'building blocks': early childhood, schooling, health, economic participation, healthy homes, safe communities, governance and leadership (see Australian Government, 2015). In Amata, a South Australian community, we took Appadurai's (2006) argument that more 'direct reflection' on research, 'it's meaning' and 'the conditions of entry' to 'the world of research, from outside its western historical home' (p. 169) was required, and an intensive period of local community researcher training was undertaken. This included workshops covering research ethics, methods, the purpose of research and the social and economic potential research offers local communities. During this process, three senior men attended sessions on the first few days, often interrupting with questions like, 'who is paying for the research?', 'who is this research for?', and 'why do they want to know about our lives?'. This is consistent with claims from Indigenous scholars such as Smith (1999), Nakata (2007f), Grande $(2004,2009)$ and Rigney (1999) that Indigenous communities are slow to trust research and its associated institutions where research has typically excluded, objectified and denigrated Indigenous peoples and their communities.

After a couple of days of senior community members interrogating narratives of research, research ethics, governmentality, and testing the claims for community benefit, the men delegated carriage of the work to younger members of the community. We were to undertake two cycles of action research using a PAR methodology and report the findings back to the community, and to the Commonwealth Government via Ninti One. The research team, aged between their early twenties and mid-forties, where keen to use the opportunity to explore questions of importance to their own lives, in particular, to understand how cultural knowledge informs participation in social and economic activities in the community. They chose two separate projects: The first titled, 'Beneath the Canvas: exploring the cultural connections that underpin the work of senior artists in Amata community' and the second, 'Bush Medicine: the benefits and the risks - economic, social and health'. These projects were chosen as the research team felt the cultural, historical and ecological knowledge held by senior community members underpins social and economic engagement in the community and there were concerns that younger people needed to engage with these cultural elements if they are to 
be sustained into the future. In particular, the researchers were keen to better understand the relationship between culture and economy through the work of Tjala Arts, the local arts centre (see tjalaarts.com.au).

Remote art centres are complex and busy spaces (see Acker \& Sullivan, 2014) working between the pragmatic demands of running an international arts business from a remote and intercultural space and serving as a vital local social, cultural and intergenerational knowledge generation space. Requests on time, expertise and resources place further pressure on art centres and outside groups such as researchers need to be sensitive to this, ensuring projects cause minimal disruption and contribute to the work and aims of the art centre. More importantly, there are ethical considerations regarding interaction with stories, knowledge and intellectual property; particular to this case was how these stories are represented and might be developed for the benefit of the narrators, their families and the wider community rather than privileging the needs of the external institutions. The research of 'Beneath the Canvas' required careful negotiation between the ACRs, the community and Tjala Arts' local decision making body, with particular care in involving senior artists in conversations about their work and how the research might benefit Anangu, the arts centre and the wider community. In this case, the artists were happy to share their stories in local language with the Anangu researchers but did not want them to be shared more publically. It was agreed that transcripts and translations would be produced and stored at Tjala Arts so that the artists could retain control and access to these stories for sharing within their families or to contribute to future social, economic or cultural outcomes as the narrators saw fit.

The process of preparing and conducting the research, producing transcripts and translations provided employment and opportunities to build capacity within the research team, a number of whom were artists already working in various capacities at Tjala Arts. In Amata community, a number of Anangu are skilled in this type of work but are committed to full time work in the school. In accordance with the commitment to building capacity and adding value, we did not request that currently employed school staff join the team, but provided an opportunity for others to develop skills and research experience in a supported and professional environment.

For the 'Bush Medicine' project, the researchers developed surveys in Pitjantjatjara language and in English to better understand the nature of engagement with bush medicine in the community, including the work of a small, locally based commercial enterprise that was underway. For the 'Beneath the Canvas' project, researchers who held close familial relationships with senior artists held interviews solely in Pitjantjatjara language with few questions, allowing opportunities for artists to share stories and describe, in depth and in local language, their approaches to cultural maintenance, knowledge transfer and the relationship between these sites, stories and the art they produce. Tjala Arts is an example of what Altman (2005) calls a 'hybrid economy', where market and non-market sources (such as government funding, see Wolf, 1998) resource dynamic spaces for social, cultural and economic activity (Acker \& Sullivan, 2014; Lovell et al., 2016; Woodhead \& Acker, 2014). These topics were selected as the researchers believed that developing an understanding of the relationship between cultural knowledge, the social context of knowledge transmission and potential economic opportunities was of utmost importance to the community. The stories documented in the research have informed and inspired subsequent presentations, publications (Tjala Arts, 2015) and exhibitions, adding value to the significant cultural and economic development model that has risen to prominence in the community as well as the national and international stage (Rothwell, 2012).

Foremost in the minds of the researchers was the importance of 'cultural capacity' (Appadurai, 2004 , p. 63) as young people consider the conditions required to drive a dynamic social, cultural, artistic and economic enterprise that embodies Anangu identity and knowledge, 
and ACRs were firmly of the view that research could assist in better understanding this process. The data was analysed by the ACRs with support, and a community presentation of the findings was made in local language to a packed audience in the school hall. The research found that families continue to engage with sites, stories and the environment, primarily as a family activity. The continual harvesting and production of bush medicine (mainly irmangka-irmangka, or eremophila alternifolia) was seen as an important social and health activity, but there was little desire to develop economic or commercial enterprises outside of a small family-run business which was operating at the time. The process of getting out of the community and interacting with the family and the environment was seen as a crucial activity for the maintenance of health, identity, wellbeing and strong, intergenerational relationships within families. In the case of the 'Beneath the Canvas' project, artists described a strong commitment to sharing and handing down important tjukurpa (stories) as vital to strengthening the identity and cultural connections of younger family members, but it was also argued that this knowledge would be vital in ensuring the continued strength and integrity of future art works, including the ongoing ability to sell higher price art pieces.

The research suggested ideas about pursuing strong and viable opportunities for economic participation were evident, and the social fabric of the family, Anangu identity and continuing connection with the land, knowledge and the tjukurpa were considered to be of primary importance for the future survival and health of families, the community and economic engagement for generations to come.

\section{Case Study 2}

In 2012, Ninti One conducted community and student surveys across three communities in the southern region of the Northern Territory where Nyangatjatjara College, an Independent Aboriginal School has secondary school campuses at Imanpa, Docker River and Mutitjulu (based at Yulara). The purpose of this work was to provide feedback to the College Board, but also to gauge community perceptions and understandings of mental health and wellbeing issues for young people, with a particular focus on the MindMatters program that was being established. The surveys were repeated 12 months later to evaluate the emerging impact of the MindMatters program and to ascertain to what degree community engagement with the College was progressing.

As with the previous case, Aboriginal Community Researchers were employed to undertake research development and to recontextualise and translate standard departmental parent opinion surveys. With the redesigned instruments they conducted interviews and participated in the analysis and report writing. In the first cycle of surveys (2012), most ACRs had not previously worked with schools, or within the field of mental health and wellbeing. The work drew heavily on previous language and conceptual development which had occurred in school-based health promotion initiatives in the Anangu Pitjantjatjara Yankunytjatjara (APY) Lands in the north-west of South Australia (see Osborne, 2013). The lack of experience and confidence with the research process and the field of the research yielded limited information and participants tended towards the practice of 'gratuitous concurrence' (Liberman, 1980), where Indigenous peoples tend to honour and manage relationships by seeking to mirror the assumptions and values of others in dialogue. Most noticeably, this is seen through the tendency to respond to all manner of questions with the answer, 'yes', or 'I don't know'. In regards to community understandings of the aspirations of young people and strategies for responding to young people experiencing mental health and wellbeing issues, the data could be interpreted to suggest in these communities, young people hold few aspirations and communities are largely unaware or unconcerned about issues relating specifically to the mental health and wellbeing of young people. 
There are methodological issues Indigenous scholars have pointed to, as I have described above, where working from institutional language, assumptions and priorities is problematic. The surveys used were based on national online surveys and despite reducing the number of questions from more than 100 to around twelve and translating the questions, the methodological approach of contacting participants and sitting down with a 20-30 minute survey is a method that often confirms what was already in the mind of the researchers and the institutions. The lack of meaningful data to inform planning and future actions points to a couple of key areas. By presenting a statement and seeking to elicit a response, the epistemological context, language and implicit assumptions of the field are pre-determined. Secondly, the content, including the professional context (such as education, mental health and wellbeing) of the surveys and the work of being a researcher were relatively unfamiliar to the ACRs and they initially lacked the confidence to move away from the constraints of the survey format and find a more suitable method for participants to share stories from their experience in relation to the education and mental health and wellbeing questions.

In 2013, the surveys were repeated. For some of the ACRs, this was now their second time around and more experienced Pitjantjatjara language speaking researchers joined the team. A methodology that asked fewer questions and allowed for deeper discussion was adopted, rather than recording responses to a series of questions derived and adapted from government surveys as the source documents. Researchers dispersed to verandas, shady areas and community spaces in far less formal interview styles, working in groups as well as interviewing individuals. The data collected in this cycle of surveys showed young people held strong, largely place-based aspirations for the future and communities described personal experiences of dealing with young people experiencing trauma and mental health and wellbeing concerns from an Anangu perspective. They explained the process of identifying a young person who is experiencing these issues and how families, communities and others such as teachers can support young people to reengage and become strong again. The language, assumptions and epistemological context of these stories brought to light capacities and thinking that remained hidden within the first cycle of surveys. Stories that emerged from the second cycle informed teachers, Anangu educators and support staff in their approach to student wellbeing, mental health and wellbeing programs, and working with families and the wider community where there were concerns about a young person's wellbeing.

This shift in methodology required ACRs to engage in a strengthening 'cultural capacity' process, where freeing the research from the epistemological and institutional constructs of a mental health and wellbeing service delivery model required reflection on how the language of the community and the language of the field can be brought together in ways that can develop understanding and ultimately, inform change. A couple of short examples of community comments demonstrate the emergence of language and thinking that was obscured in more structured interviews. In these examples, family members explain that identity and belonging underpin a sense of confidence to engage wholeheartedly and to succeed in school:

Some kids have tried so many schools. My granddaughter has tried [a boarding school] and other schools but she runs away. I talk to her about how I am her grandmother and how l'm related to help her think about education. She is doing really well at the College.

This grandmother argued that instilling a sense of confidence and belonging was critical to the educational success of her granddaughter (see Osborne, 2015a; Tjitayi \& Osborne, 2014). The following observation points to broader social and community concerns impacting young people. Particularly where families are under stress, or a mother is too young to raise a child, it is common for a child to be 'given away' to other relations to raise even if just for a short 
period. These are the kinds of issues that are visible to families, but which nonlocal (piranpa) educators, for example, have limited capacity for identifying. The logic of intervention and closing the gap are inadequate in addressing core issues family members such as this mother identify as foundational to young people's wellbeing and concerns of poor engagement with schooling:

Young people are confused about their family relationships and their identity because everyone gives their kids away. It's a problem that's hurting them. Then they want to know and find out and it's very hard. Then they turn around and say 'you're not my mother'.

These observations highlight the need for holistic, inter-disciplinary approaches where family and community involvement, affirming students' identity and belonging as learners in a school community and the development of contextualised materials and activities build student confidence in school and strengthens the network of supports around young people. This is the concept of closing the gap that Anangu educator, Katrina Tjitayi advocates for:

This is the way we can close the gaps. The child is in the middle and his family are around him. When the family surrounds the child, they can help him. Only his family can help him to change to a positive way of thinking. When the family watches over him, the child feels secure. The mother and father can help the child to be brave and to learn new things.

Our children need to learn together with us as one spirit. Our spirits are like a solid rock for them to stand on. It is only when they are standing together with us that they can stand firm without falling. (Tjitayi, in Osborne et al., 2014, p.13)

Explicit questions asking families to describe student attendance patterns yielded limited data, but as stories about young people were shared, a clear relationship between school attendance and the emotional wellbeing of students in light of community trauma was described:

They lost their friend this year when he died and they have struggled with the loss. They stopped talking and couldn't go to school. Now their tjuni [lit. stomach - a reference used as a barometer for stress/extreme emotion] is evening out [feeling better] they are returning to school in recent times.

There's a bit of sadness at the moment. Sometimes kids are at home, not attending school, not feeling good about themselves. Anangu kids go to school when they have a good feeling about themselves.

A series of family descriptions of the emotional state of young people provided educators with new perspectives on how they might support young people to engage with school and support the wider community as they monitor their young people. Shifting the research methodology to a space where more open dialogue could occur in local language, in community spaces and on community terms aided the emergence of future-oriented thinking for affecting change. Issues of student attendance can immediately be seen as more complex than simplistic strategies such as targeted attendance programs can address (see Osborne, 2014b). Rather, the context of young people's lives requires schools to work across disciplines of health, education, community development, and an approach that privileges and strengthens local epistemologies, language and culture. 
The following comment demonstrates an expectation and sense of optimism that young people will make good on the deeply held Anangu value of walytjangku kulintjaku (to think and act independently) and also indicates a sense of personal agency in the research process, where participants explain their thinking on their own terms:

I want the kids to learn to think for themselves and make a strong future. Our older generation can think for ourselves, good ideas and strong ideas but now it's our turn to sit down and watch the next generation stand up and think for themselves and build a strong future.

The logic of capacity to aspire seeks to strengthen the cultural capacities of aspiration and voice. The data that emerged from the second cycle of surveys reminded Piranpa educators of the importance of working across agencies and disciplines, but most importantly, the value of cultural capacity, families and the wider community in the education process.

\section{Synthesis of case studies}

A strengthening cultural capacity approach highlights the inadequacy of singular notions of Indigenous identity (Nakata, 2007f; Pearson, 2014) and simplistic, universal approaches to Indigenous policy. Dialogue between Anangu and the institutions of government tends to happen on location, in the community where Anangu voices and priorities are frequently positioned as subordinate. Anangu narratives demonstrated strong and clear notions of the essential attributes for young people to succeed into the future. The question, therefore, is not whether Anangu have aspirations, but whether there are available venues for the cultural capacities Appadurai (2004) describes as 'aspiration', and 'voice' to be strengthened and then to be 'heard' (Delpit, 1993; Osborne, 2014a) by others, such as Piranpa collaborators and the institutions they represent, within the externally driven national discourse of economy and development. This is where flexible, interdisciplinary research methods and institutional structures can play a significant role in strengthening cultural capacities towards social and economic justice in remote communities.

\section{The need for power-sensitive and interdisciplinary research}

Appadurai (2004) argues that future-oriented thinking integral to notions of development are held and generated from within the cultural context of communities. Nakata et al. (2012) argue for a reflective pedagogical approach to working in complex and nuanced spaces between Western and Indigenous knowledge systems, but Nakata (2007f) is critical of the academy's tendency to hegemonise, or 'discipline' Indigenous knowledge within a Western knowledge frame. This paper addresses two relevant considerations in arguing for a strengthening cultural capacity approach: Firstly, there are methodological implications for 'savaging the disciplines' (Nakata, 2007f) by challenging (Western) scientific research methods that seek to objectify and compartmentalise Indigenous peoples and knowledges; and secondly, there is the question of structuring research and research-related institutions towards a strengthening cultural capacity approach. Haraway's (2004) notion of 'power-sensitive' conversation (p. 589) can be useful in framing the grounds for collaboration between communities, academic institutions, government and non-government entities in research activity that informs policy and action. Contrary to institutional tendencies to dismiss culture and Indigenous knowledge(s) as impediments to development, cultural capacities, Aboriginal and Torres Strait Islander voices and knowledges should be central in shaping and conducting research that informs policy and action directed towards these communities. 


\section{Strengthening cultural capacity through research methodology}

The case studies describe how methodological approaches developed towards a strengthening cultural capacity logic through working from questions of interest to local ACRs and participants, and then through privileging local voices in the research. In Case Study 1, local researchers explored the relationship between culture and local economic opportunities with a view to informing younger community members of the importance of traditional knowledge in social and economic enterprise opportunities (see Acker \& Sullivan, 2014). In Case Study 2 , the first cycle of parent opinion surveys featured modest alterations made to a government survey tool, a process that generated limited data, or evidence of the cultural capacities of aspiration and voice. In the second cycle, a methodological shift towards fewer and more open questions allowed ACRs to facilitate discussions and storying in local language. This encouraged communities to explain issues relating to young people, working from local language, epistemologies and ontologies. The data from this cycle of surveys highlighted the need for education to work in a more integrated manner across school, family and community spaces, but also to collaborate across knowledge and disciplinary spaces, such as with health services, mental health and wellbeing practitioners, senior family and community members, including the utilisation of homelands as spaces for learning, healing and social re-integration. This research also informed the development of resources and activities drawing on local language, knowledge and experience to (re)negotiate understandings of mental health and wellbeing from community experiences, rather than redistributing Western knowledge perspectives and a service provision paradigm.

\section{Discussion}

These case studies highlight methodological considerations for strengthening the cultural capacities of voice and aspiration in Indigenous research spaces, but is it possible to structure flexible and interdisciplinary research practice that adopts a logic of 'capacity to aspire' (Appadurai, 2004), rather than a logic of intervention in considering the question of futures and development in remote Aboriginal and Torres Strait Islander communities?

\section{Structuring a cultural capacity approach: A regional knowledge hub concept}

The following analysis conceptualises a regional knowledge hub as a model for strengthening the cultural capacities of voice, aspiration and future-oriented thinking through research. The focus is on the tristate region in which the case studies occurred.

A significant part of the RES project has been to engage directly with Anangu in research activities and to privilege Anangu voices in dialogue about Anangu education. In particular, this includes collaborating on a number of public presentations and publications (see, for example Burton \& Osborne, 2014; Minutjukur \& Osborne, 2014; Minutjukur et al., 2014; Osborne et al., 2014; Tjitayi \& Osborne, 2014). That body of work supports Appadurai's (2004) view that culture is a rich site for future-oriented thinking, aspiration and voice, and these capacities are a natural ally to development. This type of knowledge production should not only continue, but be matured to seek continuing venues for Anangu to pursue research-informed opportunities for social, cultural, knowledge and economic development.

In remote community policy making, deficit language positioning Aboriginal people as problematic, behind or lesser (such as described by critical theorists, see Comber \& Kamler, 2004; Ladson-Billings, 1991; Milner, 2008) informs externally imagined, simplistic and universal 'solutions' that are taken up far too readily and far too often (see, for example Forrest, 2014; Hughes \& Hughes, 2012; Wilson, 2014). 
It is this deficit perspective of being behind, lesser and in need of intervention that leads to approaches that frequently exclude people who live in remote communities in all stages of the dialogue and actions. The logic of 'capacity to aspire' (Appadurai, 2004) assumes the best people to negotiate the complex process of what Nakata et al. (2012) term 'decolonial knowledge-making' (p. 124) are those who actually live the questions of negotiating notions of culture and development in their own community contexts. Along the same vein, Pearson argues Aboriginal people and communities are best placed to make economic, social and environmental decisions for the benefit of their communities, particularly where Native Title and other land-related agreements present development opportunities.

Nakata (2007a) argues a shift in language and in practice is required to address historically unequal power relations, where:

...in the academy and on the ground, the talk of Indigenous knowledge systems, rather than of cultures, does bring Indigenous knowledge, its systems, its expressions, and traditions of practice into a different relation with Western science than was possible through the discipline of anthropology. (p. 8)

The concept of a tristate knowledge hub offers potential to engage Anangu language and cultural expertise, but also offers a venue for 'decolonial knowledge-making' (Nakata et al., 2012) and strengthening cultural capacity (Appadurai, 2004). Some regions have access to specific economic opportunities such as Indigenous Protected Areas, tourism and ranger work, among others that aren't locally available elsewhere. In some cases, communities have had limited experience with Western education, whereas other communities have cohorts of qualified Anangu teachers and skilled local language educators through engagement with a longer, more consistent education history in the community. These Anangu sit within the $30 \%$ of the global population that Appadurai (2006) argues should be involved in claiming the right to research, and in gaining 'strategic knowledge', strengthening 'their claims for democratic citizenship' (p. 167).

A regional approach also draws on the dwindling capacity of Piranpa expertise. Historically, local people and language were prioritised in schooling and in running communities (see Osborne, 2015b). Piranpa were required to learn to negotiate complex knowledge interactions in local Aboriginal languages on a daily basis. Policy shifts, such as elevating the place of English language in remote education since the late 1990s (see Disbray, 2014; Graham, 1999; Nicholls, 2005) and privileging a public service paradigm in remote communities has generated fewer Piranpa with the skills, intellectual and intercultural capacity required to participate in the kind of knowledge negotiation process described. Across the tristate area, there are significant economic opportunities that can be strengthened and sustained through a cultural capacity model. At one level, drawing together senior community members from the region as language and culture experts has potential. For example, the Pitjantjatjara language Summer School, offered as an intensive two week course in January through the University of South Australia (see UniSA, 2015). This program employs and draws on the expertise of many Anangu. This intensive model could easily be offered as an autumn, winter or spring school to provide language and culture training for staff working in Anangu communities, tourism and ranger programs based at Uluru and Yulara (Ayers Rock Resort), and in Alice Springs where many services including health care are provided. Such a model increases opportunities for Anangu employment and development, and contributes to improved professional practice in Anangu contexts on a fee for service basis, making this an economically sustainable proposition. Strengthening cultural capacity in this way also contributed to the potential for researchinformed actions towards social and economic justice. 
A regional knowledge hub provides a venue for dialogue and shared learning where Anangu and Piranpa learn together. The cultural capacities of voice, aspiration and future-oriented thinking that can be strengthened through a continuing venue for flexible and interdisciplinary engagement can be returned to communities as knowledge assets (Moll et al., 1992; Zipin, 2013), but can also provide points of access and interaction for larger-scale collaborations with government programs and external organisations that can otherwise be too overwhelming to manage at a local level. Ninti One provides an organisational structure located within central Australia, offering ongoing opportunities for interdisciplinary engagement and a strengthening cultural capacity approach stretching beyond the current life of the CRC-REP.

\section{Conclusion}

Prioritising the voices and aspirations of Aboriginal and Torres Strait Islanders in remote community research requires flexible and interdisciplinary methodologies and institutional structures. Drawing on Appadurai's (2004) concept of aspiration and voice as cultural capacity, and the examples of two case studies, a research hub framework is argued for. Privileging Anangu voices in research dialogue through a Participatory Action Research method, prioritising the use of local language and exploring questions of interest to communities enabled the relationship between culture and development in the local context to be explored, and to remain core to the narrative and findings of each research project. The CRC-REP has provided opportunities for flexible, interdisciplinary research engagement and learning. A similar structure offers possibilities for remote Aboriginal communities such as in the tristate area to pursue continuing partnerships for 'decolonial knowledge-making' (Nakata et al., 2012, p. 124) as a means for pursuing research-informed social and economic justice, where community organisations, government and non-government institutions and universities can collaborate within a strengthening cultural capacity approach as outlined by Appadurai (2004).

\section{Acknowledgement}

The work reported in this publication was supported by funding from the Australian Government Cooperative Research Centres Program through the Cooperative Research Centre for Remote Economic Participation (CRC-REP). The views expressed herein do not necessarily represent the views of the CRC REP or Ninti One Limited or its participants. Errors or omissions remain with the author. We also wish to acknowledge Ninti One for providing the resources to fund this Special Issue as well as the Northern Institute, at Charles Darwin University for providing the opportunity for publication. 


\section{References}

Abbott, T. (2015). Statement to House of Representatives - Closing the Gap, Parliament House, 11 February 2015. Retrieved from http://www.pm.gov.au/media/2015-02-11/ statement-house-representatives-closing-gap-parliament-house

Abbott, T., \& Cairney, S. (2014). Collaboration and Capacity Development through the Employment of Aboriginal Community-based Researchers: Examples of the Interplay Project. Journal of Australian Indigenous Issues (Special Edition - Red Dirt Research in Remote Australia), 17(4), 164-167.

ABS. (2012). Census - Counting Persons, Place of Usual Residence. Retrieved from http://www.abs.gov. $\mathrm{au} /$ websitedbs/censushome.nsf/home/tablebuilder?opendocument\&navpos=240

Acker, T., \& Sullivan, G. (2014). More than a Place to Paint: the Complicated Business of Art Centres. Journal of Australian Indigenous Issues (Special Edition - Red Dirt Research in Remote Australia), 17(4), 168-172.

Adams, R. (2015). The death and resurrection of Nokwai on the island of Tanna, Vanuatu. Paper presented at the European Society for Oceanists 2015 Conference: Europe and the PacificMaking peace with the past. Brussels, Belgium.

Altman, J. (2005). The Indigenous hybrid economy, realistic sustainable option for remote communities: Radical approach or plain common sense? Address to the Australian Fabian Society 26 October 2005 by Jon Altman. http://www.fabian.org.au/files/051026JonAltman.pdf: The Australian Fabian Society.

Appadurai, A. (2004). The Capacity to Aspire: Culture and the Terms of Recognition. In R.V.M. Walton (Ed.), Culture and Public Action. Stanford, California: World Bank Group, Stanford Social Sciences.

Appadurai, A. (2006). The right to research. Globalisation, Societies and Education, 4(2), 167-177.

Australian Government. (2014). Closing the Gap Report: Prime Minister's Report. Canberra, ACT: Australian Government.

Australian Government. (2015). Closing the Gap Clearinghouse. Retrieved from http://www.aihw.gov.au/ closingthegap/

Bishop, R. (2011). Freeing Ourselves. Rotterdam: Sense Publishers.

Burton, R., \& Osborne, S. (2014). At the heart of learning (series paper 4 of 4): Kuranyu-kutu Nyakula Nyaan Nyanganyi? Imagining the future. AlterNative: An International Journal of Indigenous Peoples, 10(1), 33-44.

Comber, B., \& Kamler, B. (2004). Getting Out of Deficit: Pedagogies of reconnection. Teaching Education, 15(3), 293-310.

Delpit, L. (1993). The silenced dialogue: power and pedagogy in educating other people's children. In L. Weis \& M. Fine (Eds.), Beyond silenced voices: class, race, and gender in United States schools. New York: State University of New York Press.

Disbray, S. (Ed.). (2014). At benchmark? Evaluating the Northern Territory Bilingual Education Program. Melbourne, VIC: University of Melbourne.

Foley, D. (2003). Indigenous Epistemology and Indigenous Standpoint Theory. Social Alternatives, 22(1), 44-52.

Forrest, A. (2014). The Forrest Review; Creating Parity. Indigenous Jobs and Training Review. Australian Government. Retrieved from https://indigenousjobsandtrainingreview.dpmc.gov.au/forrest-review. 
Fraser, N. (2001). Recognition without Ethics? Theory, Culture \& Society June 2001, 18(2-3), 21-42.

Fraser, N. (2009). Scales of justice: Reimagining political space in a globalizing world. New York: Columbia University Press.

Fraser, N., \& Honneth, A. (2003). Redistribution Or Recognition?: A Political-philosophical Exchange. London \& New York: Verso.

Gordon, M. (2015, August 27). Indigenous reality check for Prime Minister Tony Abbott on the tip of Cape York. The Sydney Morning Herald. Retrieved from http://www.smh.com.au/federal-politics/ political-news/indigenous-reality-check-for-prime-minister-tony-abbott-on-the-tip-of-cape-york20150826-gj8584.html

Graham, B. (1999). Growing into Bilingual Education: Jottings from the Journey. Ngoonjook: A Journal of Australian Indigenous Issues, 16(Dec 1999), 55-66.

Grande, S. (2004). Red Pedagogy: Native American Social and Political Thought. Lanham: Rowman and Littlefield Publishers.

Grande, S. (2009). Red Pedagogy: Indigenous theories of redistribution (a.k.a. Sovereignty). In M.W. Apple, W.Au, \& L.A. Gandin (Eds.), The Routledge International Handbook of Critical Education (pp. 190-203). New York: Routledge.

Guenther, J., \& McRae-Williams, E. (2014). Does education and training for remote Aboriginal and Torres Strait Islanders lead to 'real' jobs? Evidence from the 2011 Census. Paper presented at the AVETRA 17th International Conference, Surfers Paradise.

Haraway, D. (2004). Situated knowledges: The science question in feminism and the privilege of partial perspective. In S. Harding (Ed.), The feminist standpoint theory reader: Intellectual and political controversies. New York \& London: Routledge.

Harding, S. (1992). After the Neutrality Ideal: Science, Politics, and "Strong Objectivity". Social Research, 59(3), 567-587.

Hughes, H., \& Hughes, M. (2012). Indigenous Education 2012 (CIS Policy Monograph 129). The Centre for Independent Studies.

Ladson-Billings, G. (1991). Returning to the sources: Implications for educating teachers of Black students. In B. Green (Ed.), Readings in equal education: Qualitative investigations into schools and schooling. London: The Falmer Press.

Ladson-Billings, G. (1999). Preparing teachers for diverse student populations: A critical race theory perspective. Review of Research in Education, 24(1), 211-247.

Liberman, K. (1980). Ambiguity and Gratuitous Concurrence in Inter-Cultural Communication. Human Studies, 3(1), 65-85.

Lovell, J., Zoellner, D., Guenther, J., Brouard, F., \& McMurtry, J. (2016). Contemporary Aboriginal settlements: Understanding mixed-market approaches. In A. Taylor, D. Carson, P. Ensign, L. Huskey, \& R. Rasmussen. (Eds.), Settlements at the Edge: Remote Human Settlements in Developed Nations. Ashgate Publishing.

Martin, K. (2006). Please knock before you enter: an investigation of how rainforest Aboriginal people regulate outsiders and the implications for western research and researchers (PhD thesis). Cairns, QLD: James Cook University.

Milner, H. R. (2008). Disrupting deficit notions of difference: Counter-narratives of teachers and community in urban education. Teaching and Teacher Education, 24(2008), 1573-1598.

Minutjukur, M., \& Osborne, S. (2014). At the heart of learning (series: paper 2 of 4): Witulya mulapa nganana mantjintjaku; From cultural devastation to cultural reinvention. AlterNative: An International Journal of Indigenous Peoples, 10(1), 15-22. 
Minutjukur, M., Patterson, V., Anderson, S., Gibson, F., Kitson, M., Martin, B., Martin, V., Morrison, H., Oldfield, N., Shannon, S., Randall, D., Namatjira, M., \& Larry, R. (2014). Voices from the 'Red Dirt' on Education. Journal of Australian Indigenous Issues (Special Edition - Red Dirt Research in Remote Australia), 17(4), 158-163.

Moll, L., Amanti, C., Neff, D., \& Gonzalez, N. (1992). Funds of knowledge for teaching: Using a qualitative approach to connect homes and classroom. Theory into Practice, 31(2), 132-141.

Moreton-Robinson, A. (1998). When the Object Speaks, A Postcolonial Encounter: anthropological representations and Aboriginal women's self-presentations. Discourse: Studies in the Cultural Politics of Education, 19(3), 275-289.

Nakata, M. (2007a). The Cultural Interface. The Australian Journal of Indigenous Education, 36(Supplement), 7-14.

Nakata, M. (2007f). Disciplining the Savages: Savaging the Disciplines. Canberra: Aboriginal Studies Press.

Nakata, M., Nakata, V., Keech, S., \& Bolt, R. (2012). Decolonial goals and pedagogies for Indigenous studies Decolonization: Indigeneity, Education \& Society, 1(1), 120-140.

Nicholls, C. (2005). Death by a Thousand Cuts: Indigenous language bilingual education programs in the Northern Territory of Australia, 1972-1998. The International Journal of Bilingual Education and Bilingualism, 8(2\&3), 160-177.

Ninti One Ltd. (2014). The key to the community intelligence of remote Australia. Retrieved from http:// www.nintione.com.au/publication/nol-0087.

Osborne, S. (2013). Kulintja Nganampa Maa-kunpuntjaku (Strengthening Our Thinking): Place-Based Approaches to Mental Health and Wellbeing in Anangu Schools. The Australian Journal of Indigenous Education, 42(Special Issue 02), 182-193. doi: 10.1017/jie.2013.25.

Osborne, S. (2014a). At the Heart of Learning (Series Paper 1 of 4) Putuna Kulini; The trouble with "hearing". AlterNative: An International Journal of Indigenous Peoples, 10(1), 3-14.

Osborne, S. (2014b). Between the bookends: what else matters other than attendance and economic development in remote education? . Paper presented at the Australian Education Union Federal Conference, Melbourne. Retrieved from http://www.crc-rep.com/publication/crc-rep-0223.

Osborne, S. (2015a). Families as foundation: Anangu perspectives on what else matters in remote education. UNESCO Observatory Multi-Disciplinary Journal in the Arts; Indigenous Education In Australia: Place, Pedagogy and Epistemic Assumptions, 4(2), 1-25.

Osborne, S. (2015b). Learning from Anangu Histories: Population Centralisation and Decentralisation Influences and the Provision of Schooling in Tri-state Remote Communities. Australian Journal of Indigenous Education, 44(Special Issue 02), 127-138. doi: 10.1017/jie.2015.17.

Osborne, S. (forthcoming). Staging standpoint dialogue in tristate education: privileging Anangu voices. (PhD thesis). Melbourne, VIC: Victoria University.

Osborne, S., Lester, K., Minutjukur, M., \& Tjitayi, K. (2014). Red Dirt Curriculum; Reimagining Remote Education Sidney Myer Rural Lecture 3 presented in Alice Springs. Alice Springs, NT: Desert Knowledge Precinct.

Pearson, N. (2014). A rightful place: Race, recognition and a more complete Commonwealth. Quarterly Essay, 55(2014), 1-72.

Rigney, D., \& Hemming, S. (2014). Is 'Closing the Gap' Enough? Ngarrindjeri ontologies, reconciliation and caring for country. Educational Philosophy and Theory, 46(5), 536-545.

Rigney, L. (1999). Internationalization of an Indigenous anticolonial critique of research methodologies: A guide to Indigenist research methodology and its principles. Wicazo Sa Review, 14(2), 109-121. 
Rothwell, N. (2012, September 13). Desert Mob lays out the legacy. The Australian. Retrieved from http://www.theaustralian.com.au/arts/visual-arts/desert-mob-lays-out-the-legacy/ story-fn9d3avm-1226472919897.

Sarra, C. (2011). Strong and Smart: Towards a Pedagogy for Emancipation. New York: Routlege.

Sen, A. (1984). Resources, values and development. Oxford: Blackwell.

Sen, A. (1995). Inequality reexamined. New York: Russel Sage Foundation; Clarendon Press.

Sen, A. (2006). Identity and violence : the illusion of destiny. London: W.W. Norton.

Smith, L. (1999). Decolonizing Methodologies: Research and Indigenous peoples. London: Zed Publishing.

Stafford-Smith, M., \& Huigen, J. (2009). From Desert Syndrome to Desert System: Developing a science of desert living. Acadamy of the Social Sciences, NT, 2(28), 8-18.

Strehlow, T. G. H. (1965). Culture, social strucutre, and environment in Aboriginal Central Australia. In R.M. Berndt \& C.H. Berndt (Eds.), Aboriginal man in Australia. Essays in honour of Emeritus Professor A. P. Elkin (pp. 121-145). Sydney, NSW: Angus \& Robertson.

Sutton, P. (2010). Linguistic Identities in the Eastern Western Desert: The Tindale evidence. In B. Baker, I. Mushin, M. Harvey, \& R. Gardner (Eds.), Indigenous Language and Social Identity; paper in hour of Michael Walsh. Canberra, ACT: The Australian National University.

Taylor, C. (1992). Multiculturalism and the politics of recognition. Princeton: University Press Princeton.

Tindale, N. B. (1937). Natives of the Western Desert of Australia. Man, 37(33), 33.

Tjala Arts. (2015). Nganampa Kampatjangka Unngu - Beneath the Canvas; The lives and stories of the Tjala artists. Adelaide, SA: Wakefield Press.

Tjitayi, K., \& Osborne, S. (2014). At the heart of learning (series paper 3 of 4): Kurunta Kanyintja; Holding knowledge in our spirit. AlterNative: An International Journal of Indigenous Peoples, 10(1), 23-32.

Tur, S., Blanch, F., \& Wilson, C. (2010). Developing a Collaborative Approach to Standpoint in Indigenous Australian Research. Australian Journal of Indigenous Education, 39(Supplementary), 58-67.

UniSA. (2015). Pitjantjatjara Language Summer School. Retrieved from http://www.unisa.edu.au/ Education-Arts-and-Social-Sciences/David-Unaipon-College-of-Indigenous-Education-andResearch/Pitjantjatjara-Language-Summer-School/.

WA Attorney General. (2008). Cross-border Justice Act 2008. Perth: Western Australian Government. Retrieved from http://www.slp.wa.gov.au/legislation/statutes.nsf/main_mrtitle_2784_homepage. html.

Wadsworth, Y. (1998). What is Participatory Action Research? Action research international, November 1998(Paper 2), 1-14.

Wilson, B. (2014). A Share in the Future; Review of Indigenous Education in the Northern Territory. Darwin, NT: Northern Territory Government.

Wolf, C. (1998). Markets or governments: Choosing between imperfect alternatives. Cambridge, Massachusetts, London: MIT Press. .

Woodhead, A., \& Acker, T. (2014). Sideways Story: Aboriginal and Torres Strait Islander Art Production and Markets. Journal of Australian Indigenous Issues (Special Edition - Red Dirt Research in Remote Australia), 17(4), 108-130.

Zipin, L. (2013). Engaging middle years learners by making their communities curricular: A Funds of Knowledge approach. Curriulum Perspectives, 33(3), 1-12. 